\title{
Economic Importance and Management of Ginger Bacterial Wilt Caused by Ralstonia solanacearum
}

\author{
Zenebe Wubshet \\ Department of Horticulture and Plan Science, College of Agriculture, Jimma University, Ethiopia. \\ *Corresponding Author: Zenebe Wubshet, Department of Horticulture and Plan Science, College of \\ Agriculture, Jimma University, Ethiopia.
}

\begin{abstract}
Ginger is a slender herbaceous perennial herb belonging to Zingiberaceae family and propagated by rhizomes. It has originated in India and currently cultivated in different countries worldwide. In Ethiopia, cultivation of ginger started during $13^{\text {th }} c$ when Arabs introduced it from India to East Africa. Like most cultivated crops, ginger is affected by biotic and abiotic factors in different parts of the world. Bacterial wilt (Ralstoniasolanacearum) is one of the most commonly known to cause disease in May crops including ginger. The pathogen enters to the roots through wounds made by transplanting, cultivation, insects or certain nematodes and through natural wounds where secondary roots emerge. Once inside the host, the bacterium has an affinity for the vascular system, where it multiplies rapidly, filling the xylem with bacterial cells and slime. After the infection is established, it moves up through the vascular system and blocks water transportation in the xylem and causes wilting. Bacterial wilt disease caused by $R$. Solanacearum widely distributed mainly in tropical, subtropical and temperate regions of the world and results severe yield losses. For instance, bacterial wilt affected 95\% of tobacco farm field in some counties of South Carolina and resulting in estimated total losses of $\$ 40$ million in both North and South Carolina. The race 4 ginger strains affected nearly all ornamental ginger species. Symptoms of the plant due to the disease ranged from flag ging or wilting to plant death. Hence, knowing these features of the disease is quite useful to analyze the conditions that determine disease development and plan sound disease management strategy. Up to now, there is no single control effective measure against the pathogen. However, some level of bacterial wilt control has been possible through the use of a combination of diverse methods. Currently, no resistance genotype was found especially in Ethiopia and the nature of the bacteria is difficult to control by chemical means which needs an integrated management programs. Hence, an urgent needs also required on establishing diseases free ginger seed rhizome production scheme both in the tissue culture and greenhouse culture.
\end{abstract}

Keywords: Bacterial wilt, phylotypes, species complex, Economic importance, management

\section{INTRODUCTION}

Ginger (Zingiber officinale Roscoe) is an important source of spices and essential oil, which belonging to Zingiberaceae family and propagated by rhizomes. Zingiberaceae family is a tropical group consisting of more than 1200 plant species in 53 genera. The genus Zingiber includes about 85 species of aromatic herbs. Edible ginger (Zingiber officinale) is one of the earliest known oriental spices and is being cultivated widely both as a fresh vegetable and dried spice. Ginger has been used throughout history as to relieve inflamed joints (Momina et al., 2011). It has originated from India, where it was introduced to Africa and Caribbean countries. However, no definite information on the primary center of domestication of ginger is available (Prabhakaran, 2013). Apart from India, ginger is also grown in China, Hawaii(USA), Indonesia, Nigeria, Thailand, Africa (Nigeria, Seraleone) etc.(Peter,2007; Ezra et al .,2017).

Cultivation of ginger was started during $13^{\text {th }} \mathrm{c}$ when Arabs introduced it from India to East Africa in Ethiopia (Girma et al. 2008; Indrias and Asfaw, 2011). Its production was mostly limited in the wetter regions of Southern nation's nationalities and people's regional states, but now a day, in addition to the southern part of the country, it is widely cultivated in Amhara and Oromiya regional and contributes $42 \%$ of growth domestic product (GDP) with the large majority of $95 \%$ vegetables (Ministry of Agriculture and Rural Development (MOARD, 2007; EIG, 2012). According to the Ethiopian external trade statistics (2008), 22.6million \$USD had been earned from ginger. 
Diseases are one of the major constraints of ginger production and of these bacterial wilt (also called Mhalior'Giger blast') is one of the most serious problems of ginger worldwide.Ralstoniasolanacearum is highly heterogeneous model bacterial pathogen of many important crops which causes severe wilting (Smith et al., 1995; Denny, 2006). It is a soil-borne bacterium, which belongs to the betaproteobacteria and responsible for bacterial wilt on more than 200 plant species from 50 botanical families, including important crops such as potato, tomato, eggplant, pepper, tobacco and banana. In fact, bacterial wilt is considered the single most destructive bacterial plant disease because of its extreme aggressiveness, wide geographic distribution, and unusually broad host range (Indrias and Asfaw, 2011; Meng, 2013).

Bacterial wilt (Ralstonia solanacearum), Pythium soft rot/rhizome rot, Leaf spot (Phyllostictazingiberi) and Nematodes were commonly known to cause disease in ginger ecology. The first Ginger bacterial wilt diseases were reported from India in 1941 by Thomas, then after a lot of reports came from Australia, China, Hawaii, Indonesia, South Korea, Malaysia, Mauritius, Nigeria, Philippines and Japan (Habetewoldet al., 2015). In Ethiopia, the bacterial disease has been reported on Potato, Tomato, Pepper, Enset, Banana and ornamentals but ginger bacterial wilt is recent reported and new to Ethiopia (Tariku et al., 2016)

Ginger bacterial wilt disease caused by Ralstonia solanacearum is known as most limiting factor in the tropical and subtropical countries include Ethiopia. In the history of spice research achievements, no disease prevalence's have been recorded on ginger. (Habetewold et al., 2015; Kurabachew and Ayana, 2016).Despite the increasing importance of the disease in the country, there is no enough information generated on the distributions and identification of the pathogen. This makes the management of bacterial wilt caused by R.solanacearum very difficult and hinders ginger production today. Hence, this article highlights some on review of the state of knowledge on the economic importance and management of ginger bacterial wilt disease with the following objectives.

\subsection{General Objective}

To review the economic importance and management of ginger bacterial wilt disease

\subsection{Specific Objectives}

To beAcquainted and familiarized with skill of scientific writing and presentation

To provide an overview of the economic importance and management of ginger bacterial wilt disease.

To familiarize the current situation of bacterial wilt disease

To identify future research areas and solve the production problems with ginger bacterial wilt disease

\section{Ginger and Recent Challenge of Production}

\subsection{Origin, Distribution and Importance of Ginger}

Ginger originated from India where it was introduced to Africa and Caribbean; however no definite information on the primary centre of domestication of ginger is available. It is now cultivated throughout the humid tropics and is a most widely used spice worldwide (Prabhakaran, 2013;Manisha et al., 2017). From the world 2,095,056 tons production of ginger, India share 7,03,000 tones from an area of 1,50,000 hectares (FAO, 2014). In Ethiopia the small and medium sized production and distribution of ginger is functioned as engine of economic growth and means of aliveting poverty.

Table1.Top Five Ginger Producing Countries

\begin{tabular}{lccc}
\hline No & Country & Production(in metric tons) & Percentageto total \\
\hline 1 & India & 702,000 & $36.6 \%$ \\
2 & China & 388,886 & $19.1 \%$ \\
3 & Nepal & 216,289 & $10.6 \%$ \\
4 & Nigeria & 160,000 & $7.8 \%$ \\
5 & Thailand & 152,630 & $75 \%$ \\
\hline
\end{tabular}

Sources: FAOSTAT Data (2014)

Ginger is perhaps the most widely used spice both for flavoring and for medicinal purposes. It is used in food preparation, confectionery, beverages, making ginger candy /preserves. In medicine, it is considered as carminative and stimulant. Ginger oil is also used as a flavoring, in pharmaceuticals and 
also in perfumery (Gosh et al. 2011; Latona et al, 2012). Moreover, ginger has a top ten health benefits include ovarian cancer treatment, control diabetes, monitoring sickness, colon cancer prevention, migraine relief, prevent cold and flu, menstrual cramp relief, Heartburn relief, reduce pain, inflammations and settle upset stomach for human being.

\subsection{Ginger bacterial wilt and the pathogen}

Bacterial wilt is most serious and devastating plant disease of economically important crops.Of the top ten bacterial species (Pseudomonas syringae, Agrobacterium tumifaciens, Xanthomonas oryzaepv.Oryzae,X. campestris pathovars, X.axonopodis pathovars, Erwinia amylovora, Xylella fastidiosa, Dickeya (former wine), (dadantanii and solani), and Pectobacterium (former Erwinia) carotovorum (Pectobacterium atrosepticum), Ralstonia solanacearum induce Ginger bacterial wilt which result great economic losses worldwide in general and in Ethiopia in particular (Mansfield et al.,2012). It is one of the most serious and damaging diseases of bacterial origins in the world which kills a number of plants, including important Solanacearum crops such as tomato, potato, pepper and eggplant each year (Alam, 2013; Henok and Getachew, 2016).

Ralstonia solanacearum grouped into Kingdom: Bacteria, Phlum: Proteobacteria, Class: Beta proteobacteria, Order:Burkholderiales, Family:Burkholderiacaea, Genus: Ralstonia, Species: Solanacearum (Tahat, and Sijam, 2010). It is widely distributed in tropical, subtropical and temperate regions of the world and causes severe wilt in many crops (Hayward, 1994;Nelson, 2013).The agent Ralstonia solanacearum is classified into five races based on the hosts affected and five biovars based on the ability to use or oxidize several hexose alcohols and disaccharides (Hayward, 1991).Race 1 strains (biovars 1, 3, and 4) are pathogenic to a broad range of hosts, including tomato (Solanumly copersicum), tobacco (Nicotiana to bacum), and peanut (Arachis hypogeal); race 2 strains (biovars 1 and 3) infect banana (Musa acuminata), plantain (Musa paradisiaca),Heliconia (Heliconia spp.) and other plants in the Musaceae family; race 3 strains (biovar 2) occur in cool upland areas in the tropics and cause severe wilt in potato (Solanaum tuberosum), tomato, and geranium (Geranium spp.),race 4 strains (biovars 3 and 4) infect ginger; and race 5 strains infect mulberry (Morus alba) (Mathew et al.,2008).

\subsubsection{Species Complex in Ralstonia solanacearum Causing Bacterial Wilt}

Table2. Taxonomic Reviews on Species Complex for R. solanacearum

\begin{tabular}{|l|l|l|}
\hline \multicolumn{1}{|c|}{$\begin{array}{c}\text { Current } \\
\text { classification(Fegan;Prior,2005) }\end{array}$} & \multicolumn{1}{|c|}{ Allen et al (2014)Fafniet al (2014) } \\
\hline Ralstonia solaracearum (pylotype II) & R.solaracearum & R.solaracearum \\
\hline Ralstonia solanacearum(phlotype I) & $\begin{array}{l}\text { Ralstonia sequeirae sp. } \\
\text { Nov }\end{array}$ & $\begin{array}{l}\text { Ralstonia pseudo solanacearum } \\
\text { sp.nov }\end{array}$ \\
\hline Ralstonia solanacearum (phylotype III) & $\begin{array}{l}\text { Ralstonia sequeirae sp } \\
\text {.nov }\end{array}$ & $\begin{array}{l}\text { Ralstonia pseudo solanacearum } \\
\text { sp.nov }\end{array}$ \\
\hline $\begin{array}{l}\text { Ralstonia solanacearum (phylotype } \\
\text { IV) }\end{array}$ & $\begin{array}{l}\text { Ralstonia syzygii sub sp. } \\
\text { Haywardii subsp. nov. }\end{array}$ & $\begin{array}{l}\text { Ralstonia syzygii sub sp. Indonesie- } \\
\text { nsiss ubsp. Nov }\end{array}$ \\
\hline Ralstonia syzygii (phylotype IV) & $\begin{array}{l}\text { Ralstonia syzygii subsp. } \\
\text { Syzygii }\end{array}$ & Ralstonia syzygiisub sp. syzygii \\
\hline $\begin{array}{l}\text { BDB(Blood Disease Bacterium } \\
\text { (phylotype IV) }\end{array}$ & $\begin{array}{l}\text { Ralstonia syzygii subsp. } \\
\text { celebensis subsp. nov. }\end{array}$ & $\begin{array}{l}\text { Ralstonia syzygii sub sp. celebes- } \\
\text { ensis subsp. nov. }\end{array}$ \\
\hline
\end{tabular}

Sources: Morias et al (2015)

\subsubsection{Epidemiology and Survival of the Pathogen}

$R$. solanacearum is the soil and plant, inhibiting bacterium enters to the roots through wounds made by transplanting, cultivation, insects, or certain nematodes and through natural wounds where secondary roots emerge (McCarter, 1991).Once inside the host, the bacterium has an affinity for the vascular system, where it multiplies rapidly, filling the xylem with bacterial cells and slime. After the infection is established it also moves up through the vascular system, the xylem, and finally blocks water transportation, which causes wilting (Tahat, and Sijam, 2010).

In the case of the ginger plant, the most common noticeable external symptoms of bacterial wilt include downward curling, and bending of leaves due to loss of turgidity, wilting, stunting and yellowing of the leaves, growth of adventitious roots in the stems and the development of narrow dark 
stripes in the infected vascular bundles beneath the epidermis may also be observed. This results from the multiplication of the bacteria in the vascular system that clog the vessels (Álvarez et, al., 2010; Kurabachew and Ayana, 2017). Subsequently $R$. solanacearum cells are set free into the soil from the roots or collapsed stems that spread to the roots of adjoining plants or to fulfill the saprophytic part of its life cycle (Denny, 2006; Habetewold et al., 2015).

The external symptoms (fig 1) result from the pathogenicity of the bacteria once inside the host, the Bacteria possess specific genes that code for hydrolytic enzymes and (hrp) genes that control disease development and the hypersensitive reactions (Boucher et al., 2001). The internal symptoms (fig 2) which are a direct reaction to infection include progressive discoloration of the vascular tissue mainly the xylem at early stages of infection and of portions of the pith and cortex as the disease progresses until complete necrosis occurs. Slimy viscous ooze typically appears on the vascular bundles of stems that have been cut across. As a result, collapse and death of the plant take place because of the degradation of xylem vessels and the destruction of surrounding tissues (Wang and Lin, 2005; Abdella, 2017).
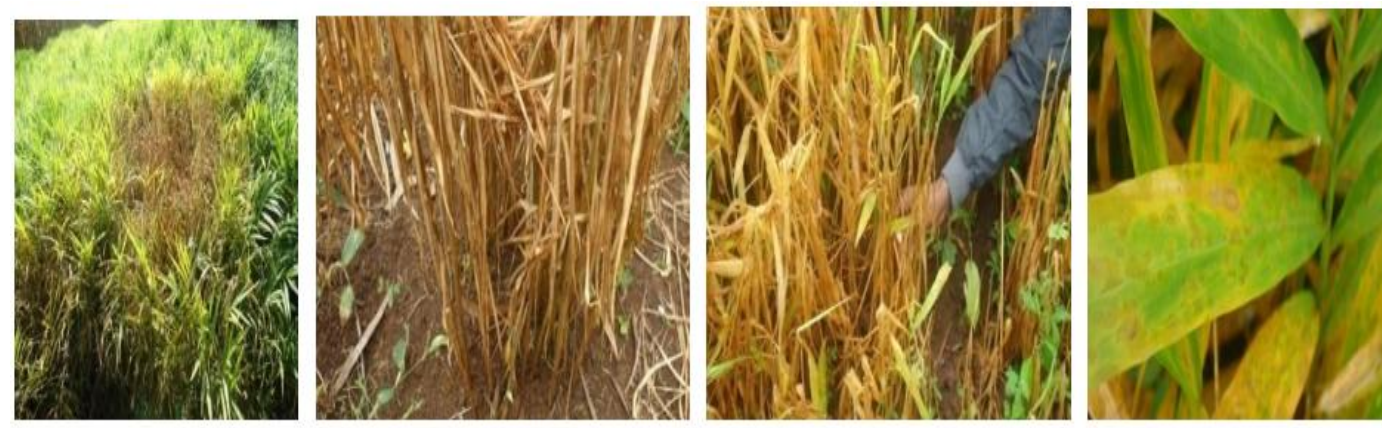

Figure1.External Symptom of Ginger Bacterial Wilt Disease
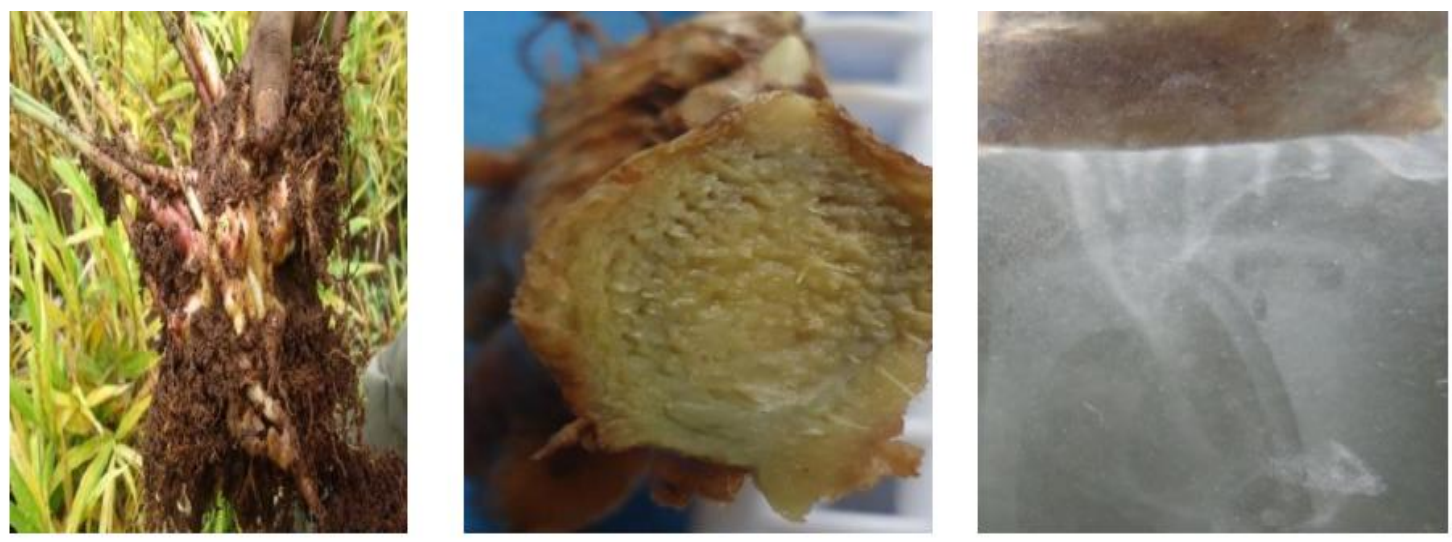

Figure2. Below Ground Symptom of Ginger Bacterial Wilt Disease on Rhizome

Generally, symptoms caused by $R$. solanacearum are varying due to the diverse nature of the pathogen in colonizing various host plants and environmental conditions (high temperature and moist soils). The bacterium returns to the soil after plant death, living as a saprophytic organism until it infects a new host plant. Transmission and dissemination of the pathogen occur through several means. The bacterium can be carried over long distances on vegetative propagating materials surviving about 2-3 years. Contaminated materials (infected seeds; irrigation water, wooden materials and crop residues) are also important sources of inoculums and contribute to short and long distance dispersal of the pathogen in the field (Wang and Lin, 2005; Kumar et al., 2016). R. solanacearum also survives in wet deep soil layers $(>75 \mathrm{~cm})$. Hence, extensive host range, wide distribution and long saprophytic survival in the environment make the control of the disease caused by $R$. solanacearum more difficult.

\subsubsection{Economic Importance of Bacterial Wilt}

The world's population is increasing every year in order to meet the demands of an ever increasing human population, the global crop production should double by 2050; however, current estimates are far below what is needed (Ray et al.,2013). Plant diseases, insects, and weeds decrease the production 
of crops worldwide by 36\%, and diseases alone have been shown to reduce crop yield by $14 \%$ (Agrios, 2005).Thus, control of plant diseases contributes to increased crop production. Among plant diseases, soil-borne diseases are considered to be more limiting than seed-borne or air-borne diseases in the production of many crops and account for 10-20\% of yield losses annually (USDA, 2003). Bacterial wilt of ginger is inflects serious economic losses in many ginger growing countries especially in the area where farmers who depends on this crop on small and marginal farmers who depend on this crop as the livelihood. It is difficult to estimate the economic losses that can be attributed directly or indirectly. The direct losses due to $R$. solanacearum vary widely according to the host, cultivar, climate, soil type, cropping pattern, geography and strain (Yuliar and Koki, 2015). Even though, there is no much information on economic impacts worldwide. Henok and Kurabachew (2016) review report showed that, bacterial wilt caused by Ralstonia solanacearum cause severe yield losses on different crops in different parts of the globe. For instance, 50-100\% of potato in Kenya, $88 \%$ of tomato in Uganda, $70 \%$ of potato in India, 95\% of tobacco in South Carolina and $100 \%$ on pepper in Ethiopia (Assefa et al., 2015).Tariku et al (2016) also reported that, a severe outbreak of ginger wilt disease identified as bacterial wilt caused by $R$. solanacearum with disease incidence of $80-100 \%$ in Ethiopia.

In addition to significant yield losses, bacterial wilt is also responsible for indirect damage such as interference with land usage and disposal of susceptible crops. The presence of $R$. solanacearum in fields discourages the planting of many vegetables on family farms and home gardens, which leads to a considerable reduction in food source (Kelman, 1998). In areas, where the organism has quarantine status, considerable economic losses can result from the prescribed destruction of entire infected crops and restriction of further cultivation on contaminated land (Elphinstone, 2005).

\subsection{Current Status of Bacterial Wilt Disease}

Bacterial wilt caused by R.solanacearum M. (Smith) is a disease widely distributed in tropical, subtropical and temperate regions worldwide. The host range of the pathogen is very wide and ginger is one of the important hosts of the pathogen (Kuma et al., 2004).Geographical distribution of the pathogen is expanding in the recent years. Bacterial wilt of ginger is reported from India, China, Japan, Indonesia, the Philippines, Hawaii and many other ginger-growing countries. R.solanacearum does not behave as a single bacterium with uniform biology and host range but a complex of variants. It is primarily rhizome-borne and is believed to be transmitted to many ginger-growing areas through latently infected rhizomes and secondary spread within the field and neighboring localities is through rain splashes and run-off water in the field.

According to statistics of Hawaii Agriculture (2009), from only 20.2ha (50 acres) that yield1 4. 5 metric tons, but the sale value declined from $\$ 3$. 0 million in 2005-2006 with concomitant decline of this important crop due to the climate change the outbreak of this disease.

Bacterial wilt is becoming a threat to ginger production for farmers of Ethiopia and total frailer of the crop due to this disease currently. Bekele et al (2011) reported that, the disease that threat ginger in Ethiopia is caused by Ralstonia solanacearum biovars III race 4 and the diseases were distributed in major ginger growing areas. In very recent, Habetewold et al (2015) and at recent time Tariku et al (2016) reported that, ginger bacterial wilt is becoming the threat to ginger production and result 80$100 \%$ incidence in the area where it produce. Currently, no resistance genotype was found in Ethiopia and the nature of the bacteria is difficult to control by chemical means which clall us to develop an integrated management program in the future.

Table 3. Incidence of Ginger Bacterial Wilt in Different Countries

\begin{tabular}{lcc}
\hline \multicolumn{1}{c}{ Country } & Incidence $(\boldsymbol{\%})$ & Reference \\
\hline India & 100 & Dohroo, 1991 \\
Hawaii & 50 & Yu et al., 2003 \\
Bengal & $22-54.6$ & Bholanatl et al., 2014 \\
Ethiopia & 81.08 & Habetewold. , et al., 2015 \\
Darjeeling & $80-84$ & Sharma et al., 2015 \\
Ethiopia & $80-100$ & Tariku et al., 2016 \\
Western Bengal(India) & 95 & Rai, 2006. \\
China & $20-50$ & Yang et al.,2015 \\
India & $>50$ & Shara and Dutta,2015 \\
\hline
\end{tabular}



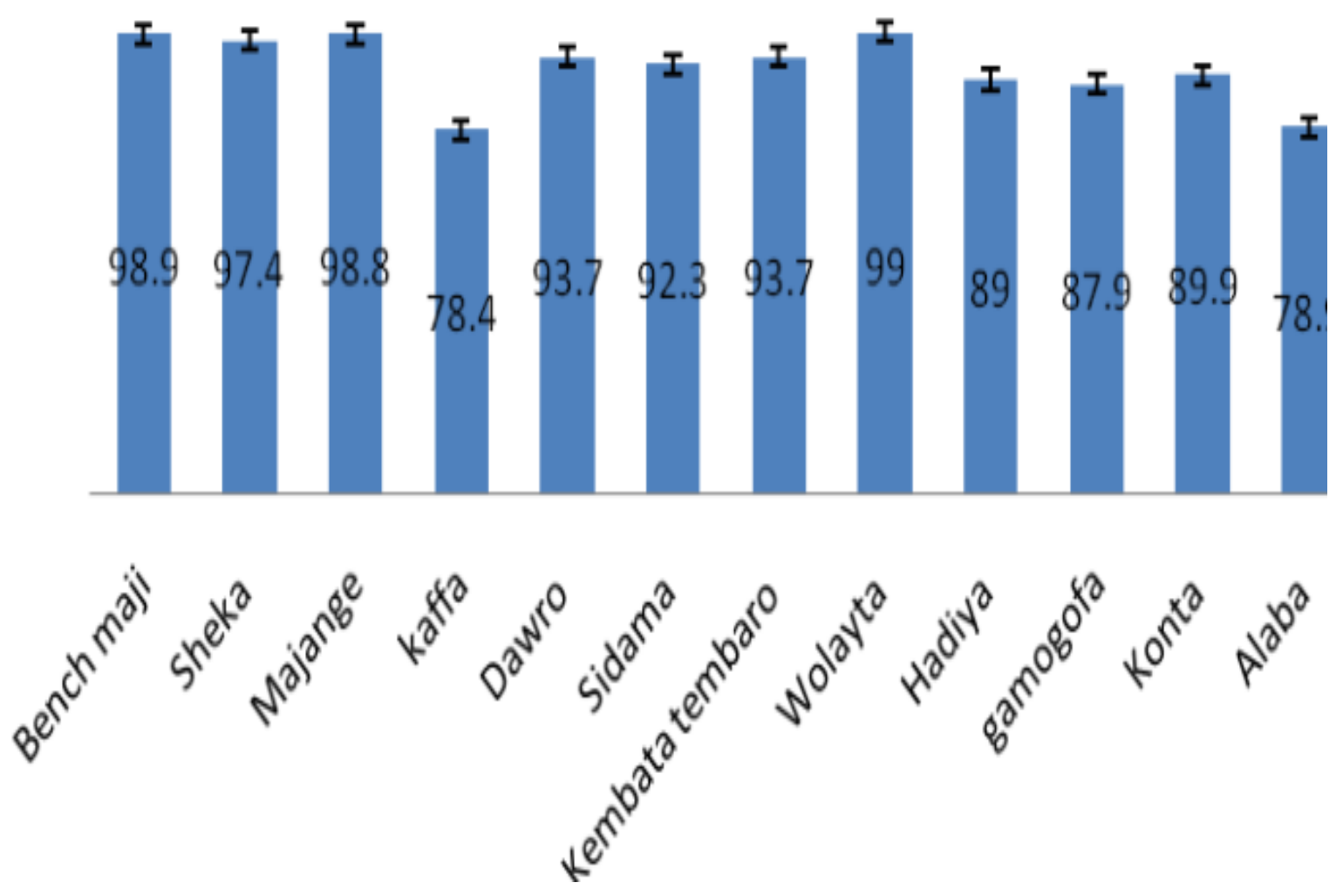

Figure3.Status of Ginger BacterialWilt inEthiopia; Source: Habtewol et al (2015)

\section{BACTERIAl Wilt MANAGEMENT APPROACHES}

Science $R$. solanacearumsoil borne pathogen, management of bacterial wilt is difficult. This is because wide host range, long survival in the soil, spread in many ways (including planting materials, irrigation water, farm implements and vectors), survives in vegetation as latent infection and genetically diverse strains (APS, 2005; Sarkar and Chaudhuri, 2016). Knowing these features of the disease is quite useful to analyze the conditions that determine disease development and plan sound disease management strategy. Up to now there is no single control effective measure against the pathogen (Lemessa and Zeller, 2007; Nelson, 2013). However, some level of bacterial wilt control has been possible through the use of a combination of diverse methods. The most efficient approaches and practices to manage bacterial wilt are the following

\subsection{Host Resistance}

Developing cultivars that are resistant to bacterial wilt is considered to be the most economical, environmentally friendly and effective method of disease control. Breeding for resistance to bacterial wilt has been concentrated on crops of wide economic importance, such as the tomato, potato, tobacco, eggplant, pepper, and peanut. The stability of resistant varieties is highly affected by pathogen strains, temperature, soil moisture and presence of root-knot nematodes, host pathogen interaction, breeding methodology and genetic linkage between resistance (Boshou, 2005; Sarkar and Chaudhuri, 2016).

\subsection{Agronomic Practices}

Cultural practices are traditional and popular approaches to manage bacterial wilt diseases. If they are used properly, can reduce the incidence and severity of bacterial wilt. Crop rotation with nonsusceptible crops reduces soil borne populations of the bacterium (Nelson, 2013; Ouyang et al, 2015).Appropriate rotation period and non-host break crops should be identified and used. Shifting planting dates to cooler periods of the year can help escape the disease. While continuous cropping with the same susceptible host plant may end up in the establishment of specific plant pathogen populations, thus crop rotation breaks this detrimental effect and result in the reduction plant diseases caused by soil borne pathogens (Janiver et al., 2007).

The preventive methods are essential for maintaining fields that are free of bacterial wilt. $R$. Solanacearum is a soil-borne bacterium and may survive for prolonged periods in soil, water, and 
plant materials (Lopez and Biosca, 2005).Thus, to keep the environment free of this pathogen, it is important to clean seeds, soil, water, and tools in order to improve crop production by preventing this disease. The use of healthy seeds that are free of pathogens is the most economical, environmentally friendly and effective method for disease control.

\subsection{Biological Control}

Biological control is another promising way to reduce bacterial wilt severity. In principle, any microbe which is able to inhibit Ralstoniaspp.population density or to reduce its pathogenicity has the potential for biological control of bacterial wilt. The most important bio-agents reported in different counties to control bacterial wilt disease are Streptomyces spp. (Xiong et al., 2014), Bacillus spp. (Wang et al., 2015), Pseudomonas spp. (Kurabachew and Wydra, 2013), avirulent Ralstonia spp. mutants (Yang et al., 2008) etc. Due to unstable performance of application of single bio-agent under field conditions, beneficial microbes that could better utilize available resources and produce antibiotics may help to improve the consistency and efficacy of bacterial wilt biocontrol (Wei et al., 2015; Hu et al., 2016).

The evidence presented here is suggestive of the potential of the isolates as biological control agents against bacterial wilt by exploiting the interaction between rhizosphere microorganisms (Yang and Guo, 2010). Generally, plant protection rendered this way can be maximized by combining different methods in an integrated disease management approach such as resistant variety, Phyto sanitation, bio-control and clean seed.

\subsection{Chemical Control}

It has been reported that, pesticide offered greater net benefit than other control methods, but not always, been the case because of the great risk. For instance, if farmers apply or use pesticides without proper care and knowledge, a percentage of the pesticide may remain in the environment for many years become a contaminant in soil and/or groundwater and be poisonous to farmers((Edwards, 2008;Gadeva and Dimitrov, 2008).

Use of essential volatile oils to kill or suppress $R$. solanacearum (Biofumigation) is also another choice to combat it. Such oils are a natural component of certain green manure crops such as mint, Palmarosaand lemongrass. When these plants are turned or plowed into the soil, several months before planting, they decompose and release the essential oils which are toxic to the pathogenic bacteria and have potential to control bacterial wilt by eliminating the pathogen in the field (Paret, 2010).Palmarosa (Cymbogogommartini), lemongrass (C. citratus) and eucalyptus (Eucalyptus globules) oils are investigated for their effects on R.solanacearum race 4 and their potential use as bio-fumigants for treating pathogen- infested edible ginger (Zingiber officinale Rose.) fields. However, the oils are very expensive if bought pre-processed, not naturally occurring as components of green-manure crops and in this case their use may not be economically feasible.

\subsection{Integrated Disease Management}

An integrated disease management (IDM) approach away, which leads to use all possible options available in a well integrated manner. The main goals of an integrated plant disease control program, which is called as integrated pest management (IPM), are to eliminate or reduce the initial inoculums, reduce the effectiveness of initial inocula, increase the resistance of the host, delay the onset of the disease and slow secondary cycles (Agrios, 2005). Control of $R$. solanacearum has proven to be a very difficult task not only due to its broad distribution and wide host range, but also the limited means of protection measures available (Genin and Boucher, 2004) and up to now there is no single effective control measure against it. Therefore, this calls for an integrated disease management strategy which is sustainable and ecologically friendly. Various integrated management options for controlling bacterial wilt have been developed in Ethiopia, Kenya and Uganda and are currently being disseminated on-farm in several other PRAPACE member countries (Kinyua et al., 2001). Management of bacterial wilt requires a multi-disciplinary approach and can only be effective if backed by systematic and continuous community awareness efforts. Generally, it is relevant to select and combine different disease control methods that are practical, economical and also environmentally healthy to control disease and improve yields ((Tusiime et al., 2000; López et al., 2008). 


\section{CONCLUSION}

Ginger (Zingiberofficinale Roscoe) is a slender herbaceous perennial herb belonging to Zingiberaceae family and propagated by rhizomes. It was originated in India andrecently becomes widely used spice throughout the world. In different parts of the world, like most cultivated crops, ginger is affected by biotic and abiotic factors. Bacterial wilt diseases caused by Ralstoniasolanacearum is becoming aserious threat to crop production worldwide. $R$.solanacearum forms a highly diverse species complex encompassing four phenotypes, five races and six biovars that have geographically distinct distribution. This species complex infects $>100$ s of plants including many economically important crops such as ginger in the main most ginger pro- ducing countries like India, China, Ethiopia etc.

In Ethiopia, bacterial disease has been reported on Potato, Tomato, Pepper, inset, Banana and ornamentals but ginger bacterial wilt is recent reported and new to Ethiopia In the history of spice research achievements, no disease prevalence's have been recorded on ginger. But very recently, in 2011/12 and 2012/13 cropping season regional plant health clinics have reported that ginger crop is being infected by unusual disease.

Since the pathogen is soil and seed born once it enters to the host, it can multiply and transmit- ted in a short time which leads to difficult to manage. Up to now, single control effective measure against the pathogen is not found. However, some level of bacterial wilt control has been possible through the use of a combination of diverse methods like host resistance, agrono -mic practices, biological control and chemical control, integrated disease management. Even though, these different approaches have been developed to control this disease, we still lack an efficient and environmentally friendly control measure for most of the host crops especially for ginger. This indicate that, inorder to increase income gained from ginger, all the responsible preson especially researchers must give to special focus for this pathogen in the future.

\section{RECOMMENDATION ANd FUtURe Prospects}

Since no resistance genotype is found especially in Ethiopia and the nature of the bacteria is difficult to control by chemical means, systemic management like integrated management programs are required. In view of the fact that, the pathogen is soil and seed born, research should focus on internal and external quarantine, control of the disease using soil amendments, biological control agents like Trichoderma and disease free seed scheme ought to get high priority. Moreover, the disease is aggravated by the recycling of seed rhizomes and farmers lack the knowledge of the nature and the life cycle of the pathogen hence, the advantage of the use of healthy planting materials need hard line intervention to increase awareness of farmers on seed quality. Generally, the pathogen spread at a very fast rate widely at present so it is the time to project research on the control strategies of the disease.

Detail work also needed on the biology, ecology, and epidemiology of the bacteria. The pathogen is soil and/or seed born, diseases management option focused on soil and seed is vital. An urgent need also required in establishing diseases free ginger seed rhizome production scheme both tissue culture and greenhouse culture.

Besides, Management of Ralstonia solanacearum has become difficult due to wide host range, vascular in nature and its occurrence throughout the year. Determination of races, weather variables for the disease development and year round survivality of the bacterium will definitely help farmers in choosing next crop to avoid the disease. Intensive study and molecular diagnosis will be needed to supplement the further knowledge.

\section{REFERENCES}

[1] Abdella I., 2017.Characterization of Bacterial Wilt Pathogen (Ralstoniasolanacearum L.) of Ginger (Zingiberofficinale Roscoe) and Its Controls Using Trichoderma and Pseudomonas Isolates. Addis Ababa Ethiopia.

[2] Agrios, G.N. 2005. Plant Pathology $5^{\text {th }}$ Edition. Academic Press, San Diego, CA. 
[3] Alarm, P., 2013. Densitometric HPTLC analysis of 8-gingerol in Zingiberofficinale extract and gingercontaining dietary supplements, teas and commercial creams. Asian Pacific journal of tropical biomedicine, 3(8), pp.634-638...

[4] Álvarez, B., Biosca, E.G. and López, M.M., 2010. On the life of Ralstoniasolanacearum, a destructive bacterial plant pathogen. Current research, technology and education topics in applied microbiology and microbial biotechnology, 1, pp.267-279.

[5] APS (American Phytopathological Society), 2005. Bacterial wilt diseases and the Ralstoniasolanacearum species complex. APS Press, American Phytopathological Society. St. Paul, Minnesota, USA.

[6] Assefa, M., Dawit, W., Lencho, A. and Hunduma, T., 2015. Assessment of wilt intensity and identification of causal fungal and bacterial pathogens on hot pepper (Capsicum annuum L.) in BakoTibbe and Nonno districts of west Shewa zone, Ethiopia. International Journal of Phytopathology, 4 (1), pp.21-28...

[7] Banerjee, S., Mullick, H.I., Banerjee, J. and Ghosh, A., 2011. Zingiberofficinale: 'a natural gold'. Int J Pharmaceutical, Bio-Sci, 2, pp. 283-94.

[8] Bekele K. 1996. Incidence and Distribution of major potato diseases in 1993 and 1994 off season in central Ethiopia (abstract). In: $4^{\text {th }}$ Annual Conference of Plant Protection Society of Ethiopia May 1996, Addis Ababa, Ethiopia.

[9] Bekele, B., E. Abate, A. Asefa and M. Dickinson. 2011. Incidence of Potato Viruses and Bacteria wilt disease in the West Amhara sub-region of Ethiopia. Journal of Plant Pathology 93 (1): 149-157.

[10] Boshou, L., 2005. A broad review and perspective on breeding for resistance to bacterial wilt...

[11] Boucher, C., Genin, S. and Arlat, M., 2001. Current concepts on the pathogenicity of phytopathogenic bacteria. Comptesrendus de l'Academie des sciences. Serie III, Sciences de la vie, 324(10), pp.915-922...

[12] Denny, T.P.2006. Plant Pathogenic Ralstonia species. p. In: Gnanamanickam SS (Ed.). Plant Associated Bacteria, Springer, And The Netherlands. Pp. 573-644.

[13] EARO. Ethiopian Agricultural Research Organization. 2000. Plant Pathology Research Strategy, Ethiopian Agricultural Research Organization (EARO), Addis Ababa.

[14] Edwards-Jones, G. 2008. Do the benefits accrue to 'pest control' pesticides?' a comment on Cooper and Dobson. Crop Prot. 27:965-967.

[15] Elphinstone, J.G., 2005. The current bacterial wilt situation: a global overview. Bacterial wilt disease and the Ralstoniasolanacearum species complex, 1, pp.9-28.

[16] Elphinstone, J.G.and Stanford, H., 1998. Sensitivity of methods for the detection of Ralstoniasolanacearum in potato tubers. EPPO Bulletin, 28 (1-2), pp. 69-70.

[17] Elsas, J.D.V., Kastelein, P., de Vries, P.M. and van Overbeek, L.S., 2001. Effects of ecological factors on the survival and physiology of RalstoniasolanacearumBv. 2 in irrigation water. Canadian journal of microbiology, 47 (9), pp. 842-854.

[18] Ezra, D., Akinola, M.O., Banta, A.L., Makarau, S.B. and Hussaini, A., 2017.Socioeconomic Assessment of Ginger Production in Jaba Local Government Area of Kaduna State, Nigeria.

[19] EU (European Union). 2003. Ralstoniasolanacearum: EPPO quarantine pest. Prepared by CABI and EPPO under the contract 90/399003.

[20] FAO, 2014. Food and Agriculture Organization, Rome. www.fao.org.in.

[21] Fortnum, B.A. 2001. Disease Management. In: South Carolina Tobacco Growers Guide. Gooden DT (Ed.) Co-operative Extension Service, Clemson, SC, USA.pp. 38-59.

[22] Geta, E. and Kifle, A., 2011. Production, processing and marketing of ginger in Southern Ethiopia. Journal of Horticulture and Forestry, 3 (7), pp. 207-213.

[23] Godiva, P and B. Dimitrov. 2008. Genotoxic effects of the pesticides Rubigan, Omiteand Rovral in rootmeristem cells of Crepiscapillaris L. Mutate. Res. 652:191-197...

[24] Granada, G.A. and L. Sequeira. 1983. Survival of Pseudomonas solanacearum in soil, rhizosphere, and plant roots. Can. J. Microbiol. 29:433-440.

[25] Habetewold, K., Bekelle, K., Kasahun, S. and Hunduma, T., 2015. Prevalence of Bacterial Wilt of Ginger (Z. Officinal) Caused by RalstoniaSolansearum (Smith) in Ethiopia. International Journal of Research Studies in Agricultural Sciences (IJRSAS), 1, pp.14-22.

[26] Hailemichael, G. and Tesfaye, K., 2008. The effects of seed rhizome size on the growth, yield and economic return of ginger (ZingiberofficinaleRosc.). Asian Journal of Plant Sciences...

[27] Hepperly, P., Zee, F., Kai, R., Arakawa, C., Meisner, M., Kratky, B., Hamamoto, K. and Sato, D., 2004. Producing bacterial wilt-free ginger in greenhouse culture.

[28] Hu, J., Wei, Z., Friman, V.P., Gu, S.H., Wang, X.F., Eisenhauer, N., Yang, T.J., Ma, J., Shen, Q.R., Xu, Y.C. and Jousset, A., 2016. Probiotic diversity enhances rhizosphere microbial function and plant disease suppression. Mbio, 7 (6), pp. e01790-16. 
[29] Janvier, C., Villeneuve, F., Alabouvette, C., Edel-Hermann, V., Mateille, T. and Steinberg, C., 2007. Soil health through soil disease suppression: which strategy from descriptors to indicators?Soil biology and Biochemistry, 39 (1), pp. 1-23.

[30] Jiang, G., Wei, Z., Xu, J., Chen, H., Zhang, Y., She, X., Macho, A.P., Ding, W. and Liao, B., 2017. Bacterial Wilt in China: History, Current Status, and Future Perspectives. Frontiers in Plant Science, 8, p.1549.

[31] Katafiire, M., Adipala, E., Lemaga, B., Olanya, M., El-Bedewy, R. and Ewell, P., 2005. Management of bacterial wilt of potato using one-season rotation crops in southwestern Uganda. Bacterial Wilt Disease and the Ralstoniasolanacearum Species Complex. American Phytopathological Society Press, St. Paul, MN, pp.197-204.

[32] Kelman, A., 1998. One hundred and one years of research on bacterial wilt. In Bacterial Wilt Disease (pp. 1-5). Springer Berlin Heidelberg. Springer-Verlag, Heidelberg. Germany. Pp. 1-5

[33] Kinyua, Z.M., Smith, J.J., Lung'aho, C., Olanya, M. and Priou, S., 2001. On-farm successes and challenges of producing bacterial wilt-free tubers in seed plots in Kenya. African Crop Science Journal, 9 (1), pp. 279-285..

[34] Kumar, A. and Hayward, A.C., 2005. Bacterial diseases of ginger and their control. Ginger-the genus Zingiber, pp.341-366.

[35] Kumar, A., Sarma, Y.R. and Anandaraj, M., 2004. Evaluation of genetic diversity of Ralstoniasolanacearum causing bacterial wilt of ginger using REP-PCR and PCR-RFLP. Current Science, pp.1555-1561.

[36] Kumar, J.S., Umesha, S., Prasad, K.S. and Niranjana, P., 2016. Detection of quorum sensing molecules and biofilm formation in Ralstoniasolanacearum. Current microbiology, 72(3), pp.297-305.

[37] Kurabachew H. And Ayana G., 2017. Bacterial wilt caused by Ralstoniasolanacearum in Ethiopia: status and management approach: a review. International journal of Phytopathology, 5(3), pp.107-119.

[38] Latona, D.F., Oyeleke, G.O. and Olayiwola, O.A., 2012. Chemical analysis of ginger root. IOSR-JAC, 1 (1), pp. 47-49.

[39] Li, B.T., Chen, X.W., and Wand, C., 1994. The occurrence and control methods for bacterial rot of ginger (Pseudomonas solanacearum), Bull. of Agric. SCI. Technol. 3, 30.

[40] López, M.M., Quesada, J.M., Penyalver, R., Biosca, E.G., Caruso, P., Bertolini, E. and Llop, P., 2008. Current technologies for Pseudomonas spp. and Ralstoniasolanacearum detection and molecular typing. In Pseudomonas syringaePathovars and Related Pathogens-Identification, Epidemiology and Genomics (pp. 3-19). Springer Netherlands.

[41] Mansfield, J., Genin, S., Magori, S., Citovsky, V., Sriariyanum, M., Ronald, P., Dow, M.A.X., Verdier, V., Beer, S.V., Machado, M.A. and Toth, I.A.N., 2012. Top 10 plant pathogenic bacteria in molecular plant pathology. Molecular plant pathology, 13(6), pp.614-629.

[42] Mathews, L. Paret1, Asoka S. De Silva1, Richard A. Criley2, and Anne M. Alvarez, 2008. Ralstoniasolanacearum Race 4: Risk Assessment for Edible Ginger and Floricultural Ginger Industries in Hawaii. .

[43] Meng F., 2013. Ralstoniasolanacearum Species Complex and Bacterial Wilt Disease. J BacteriolParasitol 4: e119.doi:10.4172/2155-9597

[44] Minima, A., Sentayehu, A., Girma, H.M. and Abush, T., 2011. Variability of ginger (Zingiberofficinale Rosc) accessions for morphological and some quality traits in Ethiopia. Intl. J. Agri. Res, 6, pp.444-457.

[45] Muthoni, J., H. Somalis and R. Melis.2012.Management of Bacterial Wilt [Rhalstoniasolanacearum Yabuuchi et al., 1995] of Potatoes: Opportunity for Host Resistance in Kenya Journal of Agricultural Science.4 (9): 64-78.

[46] Nelson, S., 2013. Bacterial Wilt of Edible Ginger in Hawai 'i. University of Hawai'i-College of Tropical Agriculture and Human resources.

[47] Nion, Y.A and Toyota, K., 2015.Recent trends in control methods for bacterial wilt diseases caused by Ralstoniasolanacearum. Microbes and environments, 30(1), pp.1-11 of Plant Sciences, 9(7), p. 385.

[48] Paret, M.L., Cabos, R., Kratky, B.A. and Alvarez, A.M., 2010. Effect of plant essential oils on Ralstoniasolanacearum race 4 and bacterial wilt of edible ginger. Plant disease, 94 (5), pp. 521-527.

[49] Ray, D.K., N.D. Mueller, P.C. West, PC and J.A. Foley.2013.Yield trends are insufficient to double global crop production by 2050.PLoS One 8: e66428.

[50] Sarkar, S.andChaudhuri, S., 2016. Bacterial wilt and its management. Current Science, 110 (8), pp. 14391445 . 
[51] Smith, J.J., Offord, L.C., Holderness, M. and Saddler, G.S., 1995. Genetic diversity of Burkholderiasolanacearum (synonym Pseudomonas solanacearum) race 3 in Kenya. Applied and Environmental Microbiology, 61 (12), pp. 4263-4268.

[52] That, M.M. and Sijam, K., 2010. Roasting solanacearum: The bacterial wilt causal agent. Asian Journal of Plant Sciences, 9(7), p.385.

[53] Tsuchiya, K., 2005. Occurrence and epidemic adaptation of new strains of Ralstoniasolanacearum associated with Zingiberaceae plants under agro-ecosystem in Japan. Bacterial wilt disease and the Ralstoniasolanacearum species complex, pp.463-469.

[54] USDA. 2003. Biological control of Fusarium wilt and other soil-borne pathogenic fungi. http://www.ars.usda.gov/research/projects/projects.htm?ACCN_NO=406590\&fy=2003.

[55] Wang, D., Shen, H., and Ran, L., 2015. Biocontrol of bacterial wilt in Eucalyptus urophylla and growth promotion by Bacillus subtilis strain CN181. Hebei J. For. Orchard Res. 30, 331-334.

[56] Wei, Z., Huang, J.F., Hu, J., Gu, Y.A., Yang, C.L., Mei, X.L., Shen, Q.R., Xu, Y.C.andFriman, V.P., 2015. Altering transplantation time to avoid periods of high temperature can efficiently reduce bacterial wilt disease incidence with tomato. Plus one, 10 (10), p. e0139313.

[57] Xiong, S., Sun, C., Shi, C., Jiang, X., and Peng, L., 2014. Screening and Identifying of antagonistic actinomycetes against Ralstoniasolanacearum in tomato. North. Hortic. 5, 114-117.

[58] Yang W, Guo J., 2010. A screening strategy of bacterial biocontrol agents towards Ralstoniawilt of ginger. Phytopathology 100: S141.

Citation: Z. Wubshet, "Economic Importance and Management of Ginger Bacterial Wilt Caused by RalstoniaSolanacearum ", International Journal of Research Studies in Agricultural Sciences, vol. 4, no. 2, p. 1-11, 2018. http://dx.doi.org/10.20431/2454-6224.0402001

Copyright: (C) 2018 Z. Wubshet. This is an open-access article distributed under the terms of the Creative Commons Attribution License, which permits unrestricted use, distribution, and reproduction in any medium,provided the original author and source are credited. 